NBER WORKING PAPER SERIES

\title{
PREDATION THROUGH REGULATION: \\ THE WAGE AND PROFIT IMPACTS \\ OF OSHA AND EPA
}

\author{
Ann P. Bartel \\ Lacy Glenn Thomas
}

Working Paper No. 1660

\section{NATIONAL BUREAU OF ECONOMIC RESEARCH \\ 1050 Massachusetts Avenue \\ Cambridge, MA 02138 \\ July 1985}

The research reported here is part of the NBER's research program in Labor Studies. Any opinions expressed are those of the authors and not those of the National Bureau of Economic Research. 


\section{Predation through Regulation: \\ The Wage and Profit Impacts \\ of OSHA and EPA}

\section{ABST RACT}

This paper documents the importance of studying the indirect effects of OSHA and EPA regulations -- the competitive advantages which arise from the asymmetrical distributions of regulatory impact among different types of firms. We argue that if the competitive advantage gained through indirect effects is sufficiently large, it can more than offset any direct costs producing a net benefit for the regulated firm and its workers. The indirect effects of OSHA and EPA regulations arise in two ways. The first source is compliance asymmetries, whereby one firm suffers a greater cost burden even when regulations are evenly enforced across firms. The second source is enforcement asymmetry, whereby regulations are more vigorously enforced against certain firms. Earlier research shows that these asymmetries do exist and are based on firm size, unionization, and regional location. In this paper we empirically document that the indirect effects produced by these asymmetries mitigate the direct costs of regulations for many firms. Large, unionized firms in the Frostbelt are clearly gaining wealth at the expense of small, nonunionized firms in the Sunbelt.

Ann P. Bartel

Graduate School of Business Columbia University New York, New York 10027 (212) 280-4419
Lacy Glenn Thomas

Graduate School of Business

Columbia University

New York, New York 10027

(212) 280-5767 


\section{Introduction}

A common error in popular expressions of political economy is the presumption that all firms oppose environmental and safety regulations because these edicts raise business costs. The flaw in this presumption arises from an exclusive focus on what we will call the "direct effects" of regulation -- the isolated, partial equilibrium impacts of regulation on single firms or individuals. ${ }^{1}$ Examples of the direct effects of environmental and safety regulations include increased safety of products and workplaces, decreased emissions of pollutants, and increased manufacturing costs. While direct effects dominate popular perceptions of regulation, the often pronounced heterogeneity among firms gives rise to additional, general equilibrium impacts we will call "indirect effects" -- the competitive advantages which arise from the asymmetrical distributions of regulatory impact among different groups of firms and workers. For example, if the cost burden of certain regulations falls heavily on one group of firms and lightly on a second group, then an indirect effect of these regulations is to provide cost advantage to the second group of firms. It is extremely important to recognize that for many firms and workers the indirect effects of regulation can outweigh, in terms of economic importance, the direct effects. If the competitive advantage gained through indirect effects is sufficiently large, it can more than offset any direct costs, producing a net benefit for the regulated firm and its workers. The CPSC swimming pool slide standard, new source

${ }^{1}$ For a more extensive discussion of the direct and indirect effects of regulation, see Bartel and Thomas (1985). 
standards of the Clean Air Act, and the OSHA cotton dust standard are among the many regulations where indirect effects have been shown to predominate. 2

As Salop (1981) and others have pointed out, activities which raise rivals' costs are, in fact, predatory in many circumstances. The three conditions necessary for activities to be regarded as predation are: competitor damage, predator benefit, and consumer damage. The first condition, competitor damage, is very likely to be satisfied by OSHA and EPA regulations. The national cost of industrial compliance with these regulations was $\$ 3.7$ billion for OSHA and $\$ 7.7$ billion for EPA in 1976 (Weidenbaum and DeFina, 1978) and mounting evidence (discussed below) indicates that this cost burden is asymmetrically distributed among various types of firms. ${ }^{3}$ As regards the second condition, predator benefit, particular groups of firms may well be sufficiently advantaged from indirect effects of regulation to experience increased profits (or wages, or both). The question of whether certain firms actually benefit from EPA and OSHA regulations is an empirical issue, and is the focus of this paper. Herein, we econometrically estimate the nature and extent of regulatory impact on industry wages and profits in the manufacturing sector of the U.S. economy.

In a narrow sense, the third condition for predation, consumer damage, is also extremely likely to be satisfied by EPA and OSHA regula-

${ }^{2}$ On the CPSC, see Viscusi (1984); on EPA, see Crandall (1983); and on OSHA, see Maloney and McCormick (1982).

${ }^{3}$ As Salop and Scheffman (1983) note, there are economic conditions under which these regulatory cost burdens need not damage competitors. Competitor damage is thus an empirical issue. 
tions. The cost increases and productivity decreases of these regulations raise prices for immediate consumers and reduce consumer surplus. 4 From a broader, and probably more correct perspective, however, for U.S. environmental and workplace safety regulations to entail "consumer damage," these regulations would need to fail a broad test of social cost-benefit. No such tests of the overall impact of these regulations is attempted in this paper, and thus in a strict sense, our argument that these regulations are predatory is incomplete. Nonetheless, a wide range of recent studies of OSHA and EPA have concluded that the actual benefits of these regulations are quite limited. ${ }^{5,6}$

In the next section, we discuss the impact of indirect effects of regulation on profits and wages and show how the first two conditions for predation, competitor damage and predator benefit, may be satisfied by the enforcement of OSHA and EPA regulations. Section III describes the empirical specifications and data sources used to test the hypotheses regarding indirect effects. The results presented in Section IV document the transfer of wealth between firms that occurs through the enforcement of OSHA and EPA regulations. Conclusions appear in Section V.

${ }^{4}$ Salop and Scheffrin also argue that there are some cases where in fact consumer surplus may rise after rivals' costs are raised.

50n OSHA, see DiPietro (1976), Mendeloff (1976), Smith (1976), Viscusi (1979), and Bartel and Thomas (1985). On EPA, see Lave and Omenn (1981) and Crandall (1983).

${ }^{6}$ Consumer damage is usually the most problematic of the three conditions. For example, the recently dismissed antitrust case against IBM contained several controversial allegations of predation against the computer company. Perhaps an appropriate view is that EPA and OSHA are at least as predatory as IBM and other industrial corporations. 
II. Direct and Indirect Effects of Regulation

Indirect effects of regulation arise from two possible sources: a "compliance asymmetry" whereby one firm suffers a greater cost burden per unit of output even when regulations are equally enforced across firms, or an "enforcement asymmetry" whereby regulations are more vigorously enforced against certain firms. There appear to be three principal sources of compliance asymmetries due to environmental and safety regulations. First, to the extent that there are economies of scale in compliance, then smaller firms suffer a larger unit-cost impact and in fact may be sufficiently disadvantaged as to exit the industry. Pashigian (1984) has provided evidence of economies of scale in compliance with EPA regulations, Neumann and Nelson (1982) have documented the exit of small mines resulting from enforcement of the 1969 Coal Mine Health and Safety Act, and we have previously documented the strong economies of scale that occur in manufacturing for compliance with OSHA regulations (Bartel and Thomas, 1985). Second, to the extent that unionized firms exhibit higher pre-regulation safety levels, enforcement of occupational safety regulations can benefit unionized firms by forcing non-union competitors to match union-dictated safety levels. Regulation can thus reduce competitive pressure on unionized firms and workers, transferring wealth to these firms and workers from the non-unionized segment of the industry. Third, both because their plants tend to be older and smaller, firms located in Northern and Midwestern states (the Frostbelt) will tend to have higher compliance costs with OSHA and EPA regulations than firms in Southern and Western States (the Sunbelt), when these regulations are evenly enforced. 
The second source of indirect effects, enforcement asymmetries, arises from administration of environmental and safety regulations that are systematically skewed against particular groups of firms or workers, and thus induce (or aggravate) competitive advantage for these particular groups. As regards OSHA, our own earlier study (Bartel and Thomas, 1985) exposed more intensive enforcement (per worker) against small and nonunion firms by the agency. To test for regional enforcement asymmetries by OSHA, we reran regression analyses from our earlier study now including a variable measuring industrial regional location. These new results are reported in an appendix to this essay and confirm that OSHA enforcement is more intensive against Sunbelt firms. As regards EPA, the environmental regulations themselves are notoriously riddled with enforcement asymmetries. Especially significant are requirements that new plants meet tighter standards than old plants, and that plants in areas of the country that are cleaner than national standards must meet tighter standards than plants in dirty areas (Crandall, 1983). Both these enforcement asymmetries burden Sunbelt plants, raising their costs against their Frostbelt counterparts.

Compliance and enforcement asymmetries are thus probably reinforcing in the case of plant size and workforce unionization, with large and unionized plants favored. These asymmetries are, however, offsetting as regards regional impact. Note that if regional enforcement asymmetries are pronounced enough to dominate regional compliance asymmetries, then Frostbelt firms will be advantaged through regulation.

The impact of EPA and OSHA on industry total rents may thus be positive or negative. In terms of direct effects alone, the impacts are, of course, negative -- higher regulation-induced production costs 
generally lower potential rents. ${ }^{7}$ But if these regulations sufficiently disadvantage small, nonunion, or Sunbelt firms in the industry, then the increase in the industry price that results from the upward shift in the supply curve, may more than offset the regulatory costs for large, unionized, or Frostbelt firms. ${ }^{8}$ Hence, rents for the industry may actually increase, on average. Figure 1 shows how the impact of regulation on industry rents depends on the firm size distribution in the industry. (Similar diagrams would hold for the percent workforce unionized or for the percent Frostbelt workforce distributions.) It can be seen in Figure 1 that the effects of EPA and OSHA regulations on industrial rents will be most negative for industries comprised exclusively of small firms. As average firm size increases, indirect effects become more significant and the effects of regulation on rents become less negative. Finally, for industries with the largest firms, regulation may well increase total and average industry rents through the exclusion of fringe competitors.

It is important to realize that the impact of regulation on industry rents will be shared between wages and profits because much of the potential increase in windfall profits through regulatory predation may be expropriated by workers. Salinger (1984) has documented this transfer to unionized workers for cross-sectional industry profits, and Moore

${ }^{7}$ Gray (1984) focused on direct effects when he studied the impact of OSHA and EPA on productivity.

${ }^{8}$ In other words, the rents of marginal firms will decline and some may be forced to exit, while the rents of inframarginal firms will rise. For an extended discussion, see Salop and Scheffman (1983). 
(1978) and others have documented the abilities of unions to force artificially increased wages for regulated firms enjoying windfall profits. Ignoring wages and examining only corporate profits would potentially severely understate the extent of regulatory impact. Our analysis, therefore, considers the impact of regulation on both profits and wages.

To measure the impact of direct and indirect effects of regulation, we specify the following relationship:

$$
\Pi_{i}=\alpha_{0}+\alpha_{1} R_{i}+\alpha_{2} R_{i} \cdot S_{i}+\alpha_{3} R_{i} \cdot U_{i}+\alpha_{4} R_{i} \cdot F_{i}+X_{i}
$$

where

$$
\begin{aligned}
& \Pi_{i}=\text { profits in industry } i \\
& R_{i}=\text { regulatory compliance costs in industry } i \\
& S_{i}=\text { average firm size in industry } i \\
& U_{i}=\text { percent of workers unionized in industry } i \\
& F_{i}=\text { percent of workers in Frostbelt in industry } i \\
& X_{i}=\text { a vector of other variables that affect profits }
\end{aligned}
$$

A similar equation may be specified for industry wages. The direct effects of regulation are captured by parameter $\alpha_{1}$, and this parameter is expected to be negative. A significant negative estimate for $\alpha_{1}$ is sufficient to demonstrate competitor damage by regulation for at least some firms. Indirect effects of regulation are captured by parameters $\alpha_{2}, \alpha_{3}$, and $\alpha_{4}$ and these parameters are expected to be positive. Note that if the magnitudes of $\alpha_{2}, a_{3}$, and $\alpha_{4}$ are large enough, then some firms and workers will enjoy increased wages and profits as a result of EPA and OSHA regulations, and predator benefit will also be documented. In the next section of this paper, we specify equation (1) more fully, and describe the data used for estimation. 
Figure 1

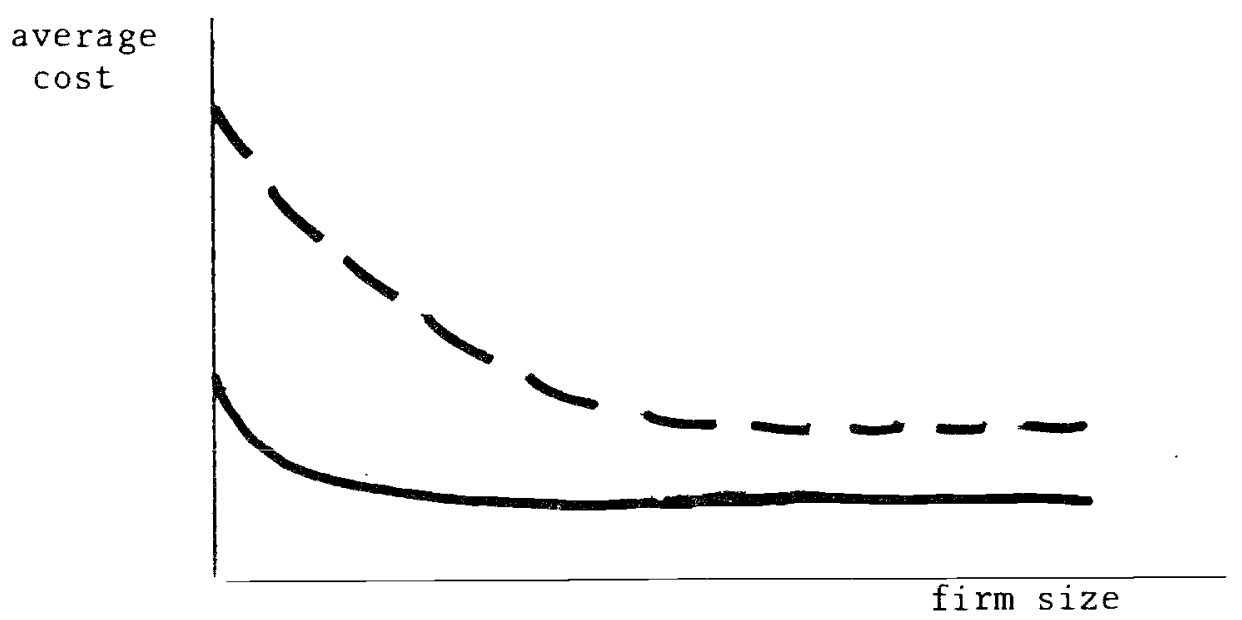

$\%$ of firms

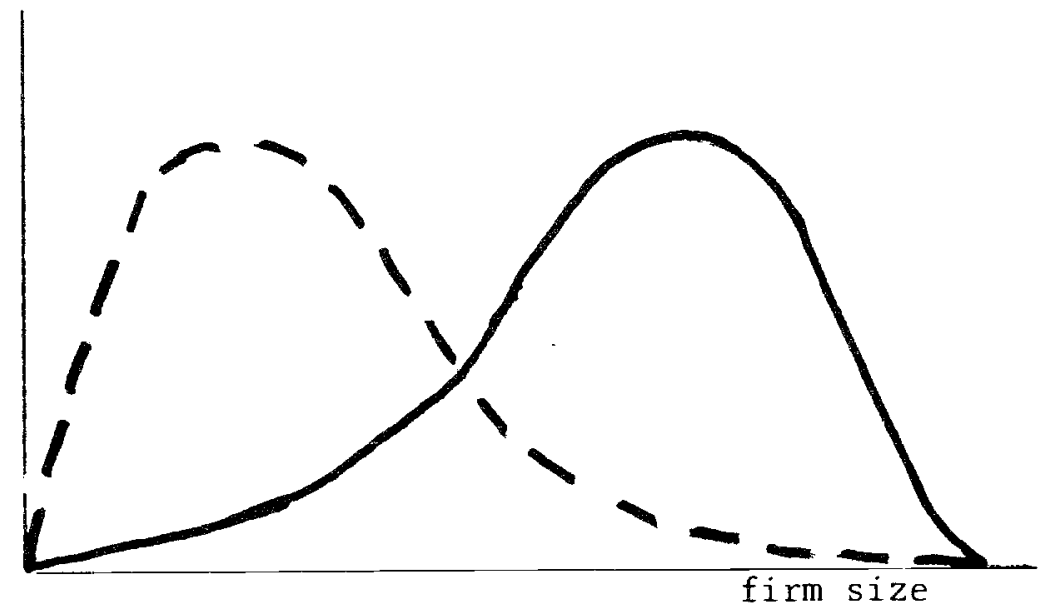

Notes: Regulation increases economies of scale for the industry; average cost curve moves from solid line to dotted line.

For industries comprised predominantly of small firms (dotted line), the profit impact is negative on average. For industries comprised predominantly of large firms (solid line), the profit impact may be positive on average. See text for discussion. 
III. Empirical Specifications and Data Sources

\section{A. Introduction}

The sections above have shown how regulation can cause transfers of wealth among rivals in an industry. In our empirical analysis we estimate the impact of OSHA and EPA regulations on the wealth of workers and firms in three-digit SIC manufacturing industries during the time period $1974-78.9$

B. Dependent Variables

The wage variable is measured by the average compensation in the industry (wages plus fringes/number of employees) and is obtained from the Annual Survey of Manufacturers.

The profit variable is "return on assets" defined as value added less labor costs, all divided by the value of assets, which is the value of structures and machines. This is also calculated from the Annual Survey of Manufacturers. While the industry's "return on assets" is a good proxy for the industry's profits, it suffers several well-known drawbacks. In spite of these problems this measure is used because of its ready availability at a level of aggregation that exactly matches the

${ }^{9}$ This time period is chosen because of limited availability of key variables outside the mid-70s. See Bartel and Thomas (1985) for a complete explanation. 
level at which industry concentration ratios and other important industry data are published. ${ }^{10}$

C. Regulation

Critical to our analysis is the appropriate method of measuring OSHA and EPA regulations. In order to document how OSHA and EPA affect industry rents, we need, in each case, a variable that captures the costs imposed on each industry by regulation. In the case of OSHA, data on the actual costs of compliance are very limited. Between 1973 and 1980, McGraw-Hill did conduct a survey of capital expenditures related to worker safety and health but the survey only covered 16 broad industry sectors in manufacturing. As a better alternative, we proxy compliance costs by the dollar value of penalties assessed against the industry by OSHA. These data are collected by OSHA and are available for detailed industry classifications.

The OSHA penalty data have two important restrictions. First, they only refer to violations of safety standards; penalties associated with violations of health standards are deleted from the data. Because safety violations constitute about $90 \%$ of total penalties, this restriction is not severe. Second, the OSHA data used for this study are restricted to the 22 states where workplace safety regulations have been continuously enforced by OSHA during the $1970 \mathrm{~s}^{11}$ Under provisions of the OSHAct of 1970 , states may retain responsibility for the development and enforcement of OSHA standards. In $1979,64 \%$ of inspections and $25 \%$ of penalties

${ }^{10}$ Freeman (1983) used this measure of profits to study the impact of unionism on profitability.

11 Those states are Alabama, Arkansas, Delaware, District of Columbia, Florida, Georgia, Idaho, Kansas, Louisiana, Maine, Massachusetts, Mississippi, Missouri, Nebraska, New Hampshire, Ohio, Oklahoma, Pennsylvania, Rhode Island, South Dakota, Texas and West Virginia. 
were generated by state agencies. Because detailed state data were not available for study, we use only data on federal enforcement of OSHA standards.

To examine the impact of OSHA on workers' wages, we divide the penalty variable by the number of workers in the 22 states for the industry and create PENEMPL; the number of workers is estimated from the Census Bureau's Country Business Patterns tapes. When the dependent variable is the return on assets, the denominator of the OSHA variable is changed to the value of assets (PENAST). Since in this case the numerator uses data based on 22 states while the denominator uses national data, we multiply PENAST by the ratio of the number of employees in the nation to the number in the 22 states, in effect, expanding the numerator to a national basis.

For EPA, a good measure of compliance costs is available. Each year, the Census Bureau publishes, for each SIC category, gross pollution abatement operating costs, which cover solid waste collection and disposal, depreciation, labor, equipment leasing, materials and supplies, and payments to governments for public sewage use. ${ }^{12}$ Pashigian (1984) has shown that most of the pollution abatement operating costs incurred from 1974 to 1978 can be considered incremental, i.e., induced by the regulatory program. For our analysis of workers' wages, we define a variable PACEMPL which equals gross pollution abatement operating costs in the

${ }^{12}$ Unfortunately, establishments in SIC Group 23, Apparel and other Textile Products; are excluded from the Census Bureau's Pollution Abatement Expenditures survey because, according to the Census Bureau, these establishments operate primarily in rented quarters where the abatement of pollution is generally arranged by the landlord. Hence, we deleted establishments in that SIC category from our analysis. 
industry divided by the number of workers in the industry using national data; for analysis of return on assets, we change the denominator to the value of assets and create PACAST.

Finally, we interact each of the four regulation variables (PENEMPL, PACEMPL, PENAST, PACAST) with average firm size, percent unionized employees in the industry, and percentage of employment in the Frostbelt in order to capture the indirect effects of regulation, or wealth transfers among various firms in the industry. Average "firm" size is calculated from the County Business Patterns data, and, is really establishment size, although we refer to it as firm size. The union variable is Freeman and Medoff's (1979) measure of percent of workers covered by collective bargaining agreements, based on the Expenditures for Employee Compensation (EEC) surveys. We chose this measure for two reasons; first, collective bargaining coverage is the most relevant concept for analysis of the impact of unionization in the labor market and second, it is the only measure available on a 3-digit SIC basis, as opposed to the Census industrial classification. The Frostbelt is defined to include states in the Northeast and Midwest; the percentage of each industry's employment in these areas is calculated from the County Business Patterns tapes.

According to the discussion in Part II, while each of the four simple regulation variables should have a negative sign, each of the twelve interaction terms should have a positive sign since regulation is presumed to benefit large firms' unionized firms, and those firms located in the Frostbelt. 
D. Other Independent Variables

The wage equation includes the following additional variables. First, we use a set of variables describing the workers in the industry: average education (EDUC), average age and its square (AGE and AGESQ), percentage of production workers (PROD), percentage of male workers (MALE), and the new-hire rate (NHR). EDUC, AGE and AGESQ are obtained from the current Population Survey; the other variables are from the Employment and Earnings files of the Bureau of Labor Statistics. Second, we add average firm size (FSIZE), the union variable (UNION), and their squares (FSSQ and UNSQ). Third, we allow for the impact of market structure by using the four-firm concentration ratio (CONC) which is obtained from the 1977 Census of Manufacturers. Following Long and Link (1983), we also interact CONC with UNION. Fourth, we consider the effect of production demand in the industry by using average overtime hours (OVER) and the percentage change in shipments during the previous year (SHPDIF). OVER is from Employment and Earnings and SHPDIF is calculated from the Annual Survey of Manufacturers. Finally, we add a regional control, SOUTH, which is the percentage of the industry's employment that is located in the south (calculated from the County Business Patterns tapes), and we add four year dummies (D75, D76, D77, and D78).

The return on assets equation includes the following additional variables. First, we include a set of variables that measure those expenses that have not already been deducted from total revenues. ${ }^{13}$ These are advertising per unit of assets (ADVERT), which is obtained from

${ }^{13}$ As the numerator is defined, only payroll and the cost of materials have been deducted. 
the Internal Revenue Service Corporate Source Book, research and development per unit of assets (RANDD) which is obtained from Scherer (1984), the value of inventories per unit of assets (INV), and new capital expenditures per unit of assets (CAPEXP); the latter are from the ASM. Second, average firm size (FSIZE), the union variable (UNION) and their squares (FSSQ and UNSQ) are added. Third, the concentration ratio is used because of the widely hypothesized relationship between concentration and profitability. Fourth, past output growth (SHPDIF) and cost of materials growth (MATDIF) are used. The latter is used to test for the impact of increases in fuel and energy costs. Finally, following weiss (1972) we test for the role of geographic dispersion by using GHERF, a Herfindahl index of employment across states, based on the County Business Patterns data. A set of year dummies is also used.

III. Results

A. Estimation Technique

The workers' wealth and return on assets equations are each estimated by nonlinear least squares and are specified as follows:

$$
\begin{aligned}
\text { HAGE }= & \alpha_{0}+\operatorname{PENEMPL}\left(\alpha_{2}+\alpha_{3} * \text { FSIZE }+\alpha_{4} * \text { UNION }+\alpha_{5} * \text { FROST }\right) \\
& +\alpha_{1} \text { *PACEMPI }\left(\alpha_{2}+\alpha_{3} * \text { FSIZE }+\alpha_{4} * \text { UNION }+\alpha_{5} * \text { FROST }\right)+\alpha_{6} \mathrm{X} \\
= & \alpha_{0}+\text { PENEMPL }\left(1+\alpha_{1} * \text { PAC }\right)\left(\alpha_{2}+\alpha_{3} * \text { FSIZE }+\alpha_{4} \text { UNION }+\alpha_{5} * \text { FROST }\right) \\
& +\alpha_{6} \mathrm{X}
\end{aligned}
$$


where PACEMPL and PENEMPL are our measures of EPA and OSHA as described in the previous section, FSIZE is average firm size, UNION is percentage of employees unionized, FROST = percentage of employment in the Frostbelt, $\mathrm{PAC} / \mathrm{PEN}=$ the ratio of pollution abatement operating costs to OSHA penalties, and $\mathrm{X}$ is a vector of other variables in the wage equation.

$$
\text { (3) } \begin{aligned}
\text { ROA }= & \beta_{0}+\operatorname{PENAST}\left(\beta_{2}+\beta_{3} * \text { FSIZE }+\beta_{4} * \text { UNION }+\beta_{5} * \text { FROST }\right) \\
& +\beta_{1} * \operatorname{PACAST}\left(\beta_{2}+\beta_{3} * \text { FSIZE }+\beta_{4} * \text { UNION }+\beta_{5} * \text { FROST }\right)+\beta_{6} Z \\
= & \beta_{0}+\operatorname{PENAST}\left(1+\beta_{1} * \frac{\text { PAC }}{\mathrm{PEN}}\right)\left(\beta_{2}+\beta_{3} * \text { FSIZE }+\beta_{4} \text { UNION }+\beta_{5} * \text { FROST }\right) \\
& +\beta_{6} Z
\end{aligned}
$$

where PACAST and PENAST are the appropriate measures of EPA and OSHA regulation as described in the previous section and $Z$ is a vector of other variables in the ROA equation. According to these specifications, five regulation parameters are estimated for each dependent variable; $\alpha_{2}-\alpha_{5}$ and $\beta_{2}-\beta_{5}$ capture the effect of OSHA while $\alpha_{1}$ and $\beta_{1}$ adjust these parameters for the differential effect of EPA. The results of estimating equations (2) and (3) are reported in Tables 1 and 2, respectively.

B. The Effects of Regulation

In column 1 of each table, we begin the analysis by excluding the regulation-interaction terms. This enables us to show the estimated impacts of OSHA and EPA when the role of indirect effects is ignored. It can be observed that, in this case, OSHA and EPA regulations have a weak 
positive effect on wages and a negative and significant effect on return on assets. In column 2 of each table, we allow for the existence of indirect effects caused by the compliance and enforcement asymmetries we discussed in Section II. Recall that our model predicted that the Iargest firms, the most heavily unionized firms, and those firms in the Frostbelt would gain competitive advantage from the enforcement of OSHA and EPA regulations. In column 2 of Table 1, we now observe that the "pure" effect of regulation on wages, the coefficient on PENEMPL, has become negative and significant while the interaction terms with firm size, unionization and Frostbelt (PENSIZE, PENUNION and PENFROST) are all positive and significant. ${ }^{14}$ This means that, in industries comprised almost exclusively of small, nonunionized firms in the Sunbelt, OSHA and EPA regulations have a significant negative effect on workers' wealth, while in industries with many large, unionized firms in the Frostbelt, the regulations significantly increase workers' wealth. In other words, the wealth of workers in large, unionized firms in the Frostbelt rises due to the competitive advantage gained from regulatory predation against their small, nonunionized, Sunbelt rivals. Such predation is accomplished by a combination of compliance and enforcement asymmetries as discussed earlier, but the relative contribution of each type of asymmetry is impossible to determine within the context of this study.

${ }^{14}$ Note that quadratic terms on firm size and percent unionized are included in all of our equations. These are added to insure that the regulation interaction terms do not capture possible nonlinearities in the effects of firm size and unionization on wages. 
Table 1

Dependent Variable: Average Compensation of Workers

\begin{tabular}{|c|c|c|c|c|c|c|}
\hline \multirow{2}{*}{$\begin{array}{l}\text { Independent } \\
\text { Variable } \\
\end{array}$} & \multicolumn{2}{|c|}{1} & \multicolumn{2}{|c|}{2} & \multicolumn{2}{|c|}{3} \\
\hline & $\beta$ & $t$ & $\beta$ & $t$ & $\beta$ & $t$ \\
\hline $\mathrm{PAC} / \mathrm{PEN} \quad\left(\alpha_{1}\right)$ & .564 & $(1.43)$ & .616 & $(3.99)$ & .633 & $(3.74)$ \\
\hline PENEMPL $\quad\left(\alpha_{2}^{1}\right)$ & 1.15 & $(1.47)$ & -12.39 & $(-5.82)$ & -11.83 & $(-4.94)$ \\
\hline PENSIZE $\quad\left(\alpha_{3}^{2}\right)$ & & & .0345 & $(3.81)$ & .0253 & $(1.19)$ \\
\hline PENSIZE 2 & & & & & .00003 & $(.49)$ \\
\hline PENUNION $\left(\alpha_{4}\right)$ & & & .0917 & $(2.91)$ & .0904 & $(2.88)$ \\
\hline PENEROST $\left(\alpha_{5}^{4}\right)$ & & & .1526 & $(7.57)$ & .1514 & $(7.47)$ \\
\hline UNION & -.0314 & $(-.49)$ & .0110 & $(.18)$ & .0110 & $(.18)$ \\
\hline UNSQ & .0018 & $(2.56)$ & .0001 & $(.19)$ & .0001 & $(.18)$ \\
\hline CONC & 9.56 & $(1.99)$ & 8.87 & $(1.96)$ & 8.79 & $(1.94)$ \\
\hline CONUNION & .0488 & $(.55)$ & .1097 & $(1.31)$ & .1136 & $(1.35)$ \\
\hline FSIZE & .0623 & $(4.56)$ & .0754 & $(5.58)$ & .0791 & $(5.08)$ \\
\hline FSSQ & -.0001 & $(-2.07)$ & -.0001 & $(-3.76)$ & -.0001 & $(-3.18)$ \\
\hline PROD & -52.71 & $(-12.09)$ & -47.97 & $(-11.54)$ & -48.12 & $(-11.55)$ \\
\hline MALE & 51.14 & $(15.85)$ & 53.95 & $(17.67)$ & 53.90 & $(17.64)$ \\
\hline EDUC & 3.30 & $\cdot(5.94)$ & 3.04 & $(5.81)$ & 3.02 & $(5.76)$ \\
\hline AGE & 7.81 & $(2.73)$ & 6.12 & $(2.27)$ & 6.27 & $(2.31)$ \\
\hline AGESQ & -.0974 & $(-2.64)$ & -.0773 & $(-2.21)$ & -.0793 & $(-2.25)$ \\
\hline NHR & -.3843 & $(-10.81)$ & -.3397 & $(-10.05)$ & -.3407 & $(-10.05)$ \\
\hline OVER & .1869 & $(4.43)$ & .2782 & $(6.83)$ & .2792 & $(6.84)$ \\
\hline SOUTH & -1.01 & $(-2.49)$ & -13.18 & $(-8.06$ & -13.09 & $(-7.97)$ \\
\hline SHPDIF & 10.81 & $(2.59)$ & 9.58 & $(2.45)$ & 9.63 & $(2.46)$ \\
\hline D75 & -1.86 & $(-1,34)$ & -1.36 & $(-1.05)$ & -1.38 & $(-1.05)$ \\
\hline D76 & 1.36 & $(1.07)$ & 1.41 & $(1.19)$ & 1.40 & $(1.18)$ \\
\hline D77 & 5.01 & $(3.95)$ & 4.62 & $(3.88)$ & 4.62 & $(3.88)$ \\
\hline D78 & 6.45 & $(5.05)$ & 5.43 & $(4.53)$ & 5.42 & $(4.53)$ \\
\hline Constant & -61.01 & $(-1.08)$ & -23.58 & $(-.44)$ & -26.30 & $(-.49)$ \\
\hline $\mathrm{R}^{2}$ & .864 & & .882 & & .882 & \\
\hline $\mathrm{N}$ & 606 & & 606 & & 606 & \\
\hline
\end{tabular}

Key to Variables:

PAC/PEN = ratio of pollution abatement operating costs to OSHA penalties; PENEMPL = OSHA penalties per employee; PENSIZE = PENEMPL $*$ average firm size; PENSIZE2 = PENEMPL * the square of average firm size; PENUNION $=$ PENEMPL $*$ percent unionized; PENFROST $=$ PENEMPL * FROST, UNION $=$ percent unionized; UNSQ = UNION $\star$ UNION; CONC = four-firm concentration ratio; CONUNION $=$ CONC $*$ UNION $;$ FSIZE $=$ average firm size; FSS2 = FSIZE $*$ FSIZE; PROD $=$ percent production workers; MALE = percent male employees; EDUC = average education of workers; $A G E=$ average age of workers; AGESQ = AGE * AGE; NHR = new hire rate; OVER = average weekly overtime hours; SOUTH $=$ share of employment in the South; SHPDIF = annual growth in shipments; $\mathrm{D} 75=1$ if $1975 ; \mathrm{D} 76=1$ if $1976 ; \mathrm{D} 77=1$ if $1977 ; \mathrm{D} 78=1$ if 1978 . 
Table 2

Dependent Variable: Return on Assets

1

Independent
Variable

$\underline{\text { Variable }}$ $\begin{array}{llr}\text { PAC/PEN } & \left(\beta_{1}\right) & 556.1 \\ \text { PENAST } & \left(\beta_{2}\right) & -.0944 \\ \text { PENASSTEF } & \left(\beta_{3}^{2}\right) & \\ \text { PENASTEF2 } & & \end{array}$

$\begin{array}{ll}\text { PENASTUN } & \left(\beta_{4}\right) \\ \text { PENASTER } & \left(\beta_{5}\right)\end{array}$

FSIZE

ESSQ

UNION

UNSQ

CAPAST

INVAST

RDAST

ADVAST

CONC

SHPDIF

MATDIF

SOUTH

GHERF

D75

D76

D77

D78

Constant

$\mathrm{R}^{2}$

$\mathrm{N}$

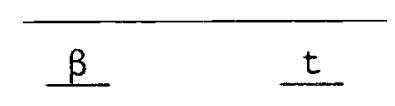

(1.94)

$(-3.08)$

$(-3.22)$

(1.84)

$(-4.34)$

$(4.60)$

(2.23)

(11.85)

$(-.84)$

(16.87)

$(-1.79)$

$(3.47)$

$(-2.14)$

$(-.54)$

(2.48)

$(-1.06)$

(.10)

$(.14)$

$(-.54)$

(.11)
2

$\beta \quad t$

3

$\underline{t} \quad t$

$\begin{array}{cr}370.3 & (2.15) \\ -.3489 & (-5.77) \\ 1.08 \mathrm{E}-04 & (.31)\end{array}$

446.4

$-.3990$

.0015

$-4.408 E-06$

.0036

.0022

$-.0018$

.000003

$-.0117$

.0001

.7656

.5044

$-2.75$

4.43

$-.0869$

1.06

(3.23)

$(-1.78)$

$(-3.87)$

(3.54)

$-1.16)$

(.16)

(.19)

$(.04)$

(1.03)
(2.48)

$(-5.43)$

(1.65)

$(-1.73)$

(3.72)

(3.65)

$(-2.78)$

(2.39)

$(-5.61)$

(4.23)

(1.78)

(12.22)

$(-1.26)$

(16.05)

$(-.86)$

(3.27)

$(-1.84)$

$(-3.84)$

(3.63)

$(-1.19)$

(.16)

$(.08)$

$(-.05)$

(1.37)
.159

.666

582

.2758

$-.0505$

.0065

.0031

$-.0022$

.216

.668

582

Key to Variables:

PAC/PEN = ratio of pollution abatement operating costs to OSHA penalties;

PENAST = OSHA penalties divided by value of assets; PENASTEF =

PENAST $*$ average firm size; PENASTEF $2=$ PENAST $*$ the square of average

firm size; PENASTUN = PENAST * percent unionized; PENASTFR = PENAST * FROST;

FSIZE = average firm size; UNION = percent unionized; FSSQ = FSIZE * FSIZE;

UNSQ $=$ UNION * UNION; CAPAST = capital expenditures divided by value of

assets; INVAST = value of inventories divided by value of assets;

RDAST = expenditures on R\&D divided by value of assets; ADVAST = advertising expenditures divided by value of assets; CONC = four-firm concentration ratio; SHPDIF = annual change in value of shipments;

MATDIF = annual change in materials costs; SOUTH = share of employment in the South; GHERF = geographic Herfindahl index; D75 = 1 if 1975;

$\mathrm{D} 76=1$ if $1976 ; \mathrm{D} 77=1$ if $1977 ; \mathrm{D} 78=1$ if 1978 . 
In column 2 of Table 2 , we add the regulation-interaction effects to the returns on assets equation. ${ }^{15}$ We find strong evidence that unionized firms gain wealth relative to nonunionized firms as a result of the enforcement of OSHA and EPA. Additionally, firms in the Frostbelt benefit relative to those in the Sunbelt, and the effect is very significant. The hypothesized firm size effect, although of the right sign, is extremely weak. In column (3) we consider whether this is due to the hypothesized economies of scale dissipating at very large firm sizes. This is done by adding another interaction term, PENASTEF2, which equals PENAST $^{*}\left(\right.$ FSIZE) ${ }^{2}$. According to the results in column (3), PENASTEF is now positive, while PENASTEF2 is negative and each is significant at the 10 percent level. 16 Economies of scale disappear at an establishment size of 205. This corresponds to the ninetieth percentile of the establishment size distribution in our sample. Hence, our argument that industries with many large firms experience an increase in wealth relative to industries dominated by small firms, as a result of OSHA and EPA regulation, holds true, but the effect dies out very promptly as firm size increases. In contrast, when PENSIZE2 was comparably added to the wage equation, no diminution of the firm size effect was found as firm size increased.

${ }^{15}$ Again, note that quadratic terms on firm size and unionization are included in these equations. See footnote 15.

${ }^{16}$ Note that in column (3) of Table 1 , we also included an interaction term with the square of firm size, PENSIZE2, but this variable was not significant. 
C. Other Variables

The regressions in Tables 1 and 2 contain other variables that were used to properly specify the employee compensation and return on assets equations. Since the effects of these variables are not our focus and other researchers have thoroughly discussed their impacts, we do not discuss them in detail here. The effects of the variables in the employee compensation equation are all consistent with previous research and there are no surprises here. ${ }^{17}$ In the return on assets equation, one result is unexpected, namely that $R \& D$ does not have a positive effect. This clearly disputes other research and may be due to the imperfect matching of the R\&D data with the Survey of Manufacturers data. We are confident, however, that this does not contaminate the estimation of the coefficients on the regulation variables. When we restricted the coefficient on RDAST to be positive, the coefficients on all of the regulation variables, both simple and interaction terms, increased in the absolute values of both magnitude and significance.

\section{Conclusions}

This paper has documented the importance of studying the indirect effects of OSHA and EPA regulations -- the competitive advantages which arise from the asymmetrical distributions of regulatory impact among different types of firms. We have argued that if the competitive advantage gained through indirect effects is sufficiently large, it can more

17 The insignificant effect of UNION Is due to the inclusion of UNSQ. When UNSQ is deleted, UNION is positive and significant in all columns of Table 1 . 
than offset any direct costs producing a net benefit for the regulated firm and its workers. The indirect effects of OSHA and EPA regulations arise in two ways. The first source is compliance asymmetries, whereby one firm suffers a greater cost burden even when regulations are evenly enforced across firms. The second source is enforcement asymmetry, whereby regulations are more vigorously enforced against certain firms.

Earlier research has shown that these asymmetries do exist and are based on firm size, unionization, and regional location. In this paper, we have empirically documented that the indirect effects produced by these asymmetries mitigate the direct costs of regulation for many firms. Large, unionized firms in the Frostbelt are clearly gaining wealth at the expense of small, nonunionized firms in the Sunbelt. While the estimated regulation-interaction effects were significant in Tables 1 and 2 , the t-values by themselves do not indicate the magnitude of the wealth transfer. We show this in Table 3 where we evaluate the derivatives of regulation in both the wage and profit equations. The effect is estimated by letting firm size, unionization and the Frostbelt employment share each take on, in turn, a value of zero, the mean, the median or the maximum, while the other two variables are set to equal to their means. This exercise enables us to determine the relative importance of the indirect effects created by each of the variables. The findings in Table 3 show that workers in large, unionized firms in industries that have a high Frostbelt employment share benefit substantially. The Frostbelt effect is the largest of the three tested here; evaluating its effect from minimum to maximum values of FROST at mean values of PENEMPL and WAGE we find a $5.4 \%$ increase in wages. According to the profit equation, firms in heavily unionized Frostbelt industries also profit from OSHA and 
EPA regulation; the comparable effect of FROST on ROA is an $8.7 \%$ increase from minimum to maximum ${ }^{18}$ medium-sized firms, but dissipates beyond this level. Another surprising result here is that the union effect is the strongest of the three variables; evaluating its effect, we find a $12.8 \%$ increase in ROA from minimum to maximum values of UNION. One interpretation of why the wages and profits results differ is that workers may be able to expropriate the bulk of the windfall wealth that is created by regulation, and hence, relatively weak firm size effects are observed in the case of profits. Alternatively, we feel that the unusual results from the profit equation (e.g. weak firm size effect, very large union effect) are due to admittedly inferior profit data. The difficulties in measuring profits are well known, and, in our case, our profit measures probably includes a number of expenses for which we have been unable to control. Hence, we would argue that the wealth transfer inferred from the profit equation is subject to potential measurement error, and the results from the wage equation might be given more attention.

With this caveat in mind, we feel that our findings are extremely provocative. We have shown that regulation has become a predatory device that can be utilized to enhance the wealth of those firms that are best able to comply and to reduce the wealth of rivals who suffer higher regulatory cost burdens. Discussions about regulatory reform or deregulation obviously need to incorporate this model of regulation in order to accurately evaluate the impact of any proposed changes.

${ }^{18}$ The mean of wage is 101.9 in 1972 dollars. The mean of ROA is .8706 , which is so large because of several corporate expenses (including capital costs, advertising, research, etc.) that are not deducted from the numerator but rather are controlled for by independent variables. The mean of PENEMPL is .382 and of PENAST is .344. 
Table 3

Estimated Total Effects of Regulation on Wages and Profits*

Wage Equation

Derivative of Regulation: (from Column 2 in Table 1)

$-12.39+.0345($ FSIZE $)+.0917($ UNION $)+.1526($ FROST $)$

\begin{tabular}{|c|c|c|c|c|}
\hline Variable & At Zero & At Mean & At Median & At Maximum \\
\hline FSIZE & -1.78 & 2.04 & 0.69 & 5.57 \\
\hline UNION & -2.03 & 2.04 & 2.10 & 6.22 \\
\hline FROST & -4.51 & 2.04 & 1.65 & 9.88 \\
\hline
\end{tabular}

\section{Profit Equation}

Derivative of Regulation: (from Column 3 in Table 2)

$-.3990+.0015(\text { FSIZE) Q-4.41E-06(FSIZE })^{2}+.0036($ UNION $)+.0022($ FROST)

$\begin{array}{lcccc}\text { Variable } & \text { At Zero } & \text { At Mean } & \text { At Median } & \text { At Maximum } \\ \text { FSIZE } & -.1457 & -.0332 & -.0610 & -.0560 \\ \text { UNION } & -.1927 & -.0332 & -.0307 & .1313 \\ \text { FROST } & -.1275 & -.0332 & -.0386 & .0780\end{array}$

*Derivative values are computed using either zero, mean, median, or maximum values for the listed variable in each row and mean values for the other two variables. Median values are 71.5 (FSIZE), 45 (UNION), 40.4 (FROST). Means are 110.6 (FSIZE), 44.3 (UNION), 42.9 (FROST). Maximum values are 520.7 (FSIZE), 90 (UNION) and 94.3 (FROST). 


\section{APPENDIX}

In the absence of existing studies of regional enforcement asymmetries by OSHA, we elected to reestimate regression equations from an earlier study (Bartel \& Thomas, 1985). Explanations of specification and descriptions of data are contained in the 1985 study and are not repeated here. One feature of the data should be noted, however. For reasons discussed in the text of this essay, availability issues limited OSHA enforcement data to a 22 state region of federal enforcement. Other data used for the regression results below were comparably restricted to this 22 state region. Thus the variables listed below are different from those used in the text as they are drawn from a different sample. The 22 states are as follows:

Frostbelt: Delaware, District of Columbia, Kansas, Maine, Massachusetts, Missouri, Nebraska, New Hampshire, Ohio, Pennsylvania, Rhode Island, South Dakota, and West Virginia

Sunbelt: Alabama, Arkansas, Florida, Georgia, Idaho, Louisiana, Mississippi, Oklahoma, and Texas.

Five enforcement variables were examined with OLS results reported in Table 3. The Target Industry Program (TIP) was the focus of OSHA enforcement activities in 1972 and 1973. The determinants of the OSHA decision to include industries in the TIP are examined using data for 1974 only (earlier data for FSIZE and FROST limited to the 22 states were not available). For 1974 to 1978 , pooled cross-section time-series data are used. Note that enforcement asymmetries against small, nonunion, and Sunbelt firms are documented. Also note that enforcement asymmetries against small firms basically disappeared by 1978 , while regional enforcement asymmetries became more pronounced. 
Table 4

Enforcement Asymmetries by OSHA

Dependent Variable

Independent

Variable

TIP

INSPEMP

INSPEMP

LOSTDAY

CMPLT
CMPLT $*$ YR

$.155 \quad(8.69)$

.350

$-.012(-.92)$

.523

$(9.77)$

334

.338

FSIZE

FSIZE $\approx$ YR

$-.051(-4.85)$

$-.322(-15.04)$

.115

UNION

UNION*YR

FROST

FROST:YR

D74

D75

D76

D77

$-.102(-6.18)$

$-.526$

.113

$-.066$

$-.080 \quad(-2.40)$

$=.012$

$-.200(-4.55)$

$-.199(-2.24)$

.017

$-.094$

$1.291 \quad(22.44)$

$-.745$

1.217

(21.03)

$-.264$

.523

(9.65)

$-.416$

.205

$(3.84)$

$-.261$

Constant

$\mathrm{R}^{2}$

$-.379(-1.84)$
.288

$-3.184 \quad(-7.65)$

$-1.852$

.787

118

594

$(-15.86)$

$(-1.58)$

$(-.59)$

$(-2.71)$

$(-1.14)$

$(-1.54)$

$(-1.31)$

$(-1.59)$

$(-3.72)$

594

\section{Key to Variables}

TIP = zero-one dummy variable (1974 only) for inclusion of industry in TIP; INSPEMP = OSHA inspections per employee; LOSTDAY= lost workdays per employee; CMPLT = formal complaints to OSHA per employee; FSIZE = average establishment size; UNION = percentage of employees unionized; FROST = percentage of employees in Frostbelt. *YR = left variable is multiplied by (year - 1974); D74, etc. = zero-one year dummy variables.

Notes: All variables except TIP, Frost, and year dummies are in logarithms.

All data are restriced to the 22-state region of federal enforcement. 


\section{References}

Bartel, Ann P. and Lacy Glenn Thomas, "Direct and Indirect Effects of Regulation: A New Look at OSHA's Impact," Journal of Law and Economics, April 1985 .

Crandall, Robert, Controlling Industrial Pollution: The Economics and Politics of Clean Air, Washington, DC: Brookings, 1983.

DiPietro, Aldona, "An Analysis of the ASHA Inspection Program in Manufacturing Industries 1972-1973," Draft Technical Analysis Paper, U.S. Dept. of Labor, August 1976.

Freeman, Richard, "Unionism, Price-Cost Margins, and the Return to Capital," NBER Working Paper No. 1164, July 1983.

Freeman, Richard and James Medoff, "New Estimates of Private Sector Unionism in the United States," Industrial and Labor Relations Review (January, 1979).

Gray, Wayne, "The Impact of OSHA and EPA Regulation on Productivity," NBER Working Paper NO. 1405, July 1984.

Robert Leone, Environmental Controls, Lexington, MA: Lexington Books, 1976.

and John Jackson, "A Case Study of Water Pollution Controls in the Pulp and Paper Industry," Harvard Business School working paper $78-6$.

Long, James and Albert Link, "The Impact of Market Structure on Wages, Fringe Benefits, and Turnover," Industrial and Labor Relations Review (January, 1983).

Maloney, Michael and Robert McCormick, "A Positive Theory of Environmental Quality Regulation," Journal of Law and Economics, April 1982.

Mendeloff, John, "An Evaluation of the OSHA Program's Effect on Workplace Injury Rates: Evidence from California through 1974," Report prepared for ASPER, U.S. Dept. of Labor, July 1976.

Moore, Thomas Gale, "The Beneficiaries of Trucking Regulation," Journal of Law and Economics, October 1978.

Neumann, George and Jon Nelson, "Safety Regulation and Firm Size: Effects of the Coal Mine Health and Safety Act of 1969," Journal of Law and Economics (October, 1982).

Pashigian, Peter, "The Effect of Environmental Regulation on Optimal Plant Size and Factor Shares," Journal of Law and Economics, April 1984. 
Salinger, Michael, "Tobin's q, Unionization and the Concentration-Profits Relationship," Rand Journal of Economics, (Summer, 1984).

Salop, Steven, "Introduction," in Salop, ed., Strategy, Predation, and Antitrust Analysis, Washington, D.C.: Federal Trade Commission, 1981.

, and David Scheffman, "Raising Rivals' Costs," American Economic Review (May, 1983).

Scherer, F. M., "Using Linked Patent and R\&D Data to Measure Interindustry Technology Flows," in Zvi Griliches, ed., R\&D, Patents, and Productivity, University of Chicago Press, $19 \overline{84 .}$

Smith, Robert J., The Occupational Safety and Health Act: Its Goals and Achievements, American Enterprise Institute, Washington, D.C., 1976.

Viscusi, W. Kip, Regulating Product Safety, American Enterprise Institute, Washington, D.C., 1984.

, "The Impact of Occupational Safety and Health Regulation," Bell Journal of Economics, Spring 1979.

Weiss, Leonard, "The Geographic Size of Markets in Manufacturing," Review of Economics and Statistics, 1972.

Weidenbaum, Murray L. and Robert DeFina, "The Cost of Federal Regulation of Economic Activity," AEI Reprint No. 88, May 1978. 